$\begin{array}{ll} & \text { Etnográfica } \\ \text { etnográfica } & \text { Revista do Centro em Rede de Investigação em }\end{array}$

Antropologia

vol. $14(1) \mid 2010$

Vol. $14(1)$

\title{
Ethnographies of new clinical encounters: immigrant's emotional struggles and transcultural psychiatry in Portugal
}

Etnografias de novos encontros clínicos: as batalhas emocionais do imigrante e a psiquiatria transcultural em Portugal

\section{Chiara Pussetti}

\section{OpenEdition}

\section{Journals}

\section{Edição electrónica}

URL: https://journals.openedition.org/etnografica/174

DOI: 10.4000/etnografica. 174

ISSN: 2182-2891

\section{Editora}

Centro em Rede de Investigação em Antropologia

\section{Edição impressa}

Data de publição: 1 fevereiro 2010

Paginação: 115-133

ISSN: 0873-6561

\section{Refêrencia eletrónica}

Chiara Pussetti, «Ethnographies of new clinical encounters: immigrant's emotional struggles and transcultural psychiatry in Portugal», Etnográfica [Online], vol. 14 (1) | 2010, posto online no dia 21 outubro 2011, consultado o 12 fevereiro 2022. URL: http://journals.openedition.org/etnografica/174 ; DOI: https://doi.org/10.4000/etnografica.174

\section{(c) (†) 8}

Etnográfica is licensed under a Creative Commons Attribution-NonCommercial 4.0 International License. 


\title{
Ethnographies of new clinical encounters: immigrant's emotional struggles and transcultural psychiatry in Portugal
}

\section{Chiara Pussetti}

\begin{abstract}
Based upon two years of fieldwork in a mental health service for migrants in Lisbon, this article underlines how the psychiatric interpretation of the emotional experience of displacement, homelessness and (non) belonging in migrants can be influenced by colonial legacies. These legacies - incorporated, despite the best of intentions, as a constitutive element of diagnosis and treatment into the therapeutic practices of psychiatric counselling - pathologize experiences and behaviours of marginalized people of non-Western origins, reproducing discriminative attitudes and institutional racism.
\end{abstract}

KEYWORDS: anthropology of emotion, critical medical anthropology, ethnopsychiatry, colonial legacies, African diaspora.

\begin{abstract}
You came to me, Hippocrates, to give me the hellebore, giving credit to foolish men by whom my job is considered madness. I was writing about the harmony of the cosmos, the description of the pole and about the stars [...] If you, convinced that I was insane, had made me drink this medicine, my wisdom would have become madness and your art would have been blamed as responsible of creating folly [Letter of Democritus to Hippocrates]. ${ }^{1}$
\end{abstract}

IN A WORLD OF INCREASING HUMAN MOBILITY, MANY HEALTH outcomes are shaped by interactions between care providers and care recipients who are embedded in different discursive practices and culturally based systems of meaning. In these settings, caretakers and users often deal with a wide variety of unfamiliar health practices and behaviours. In these new clinical encounters suffering is organized, experienced and expressed in terms of an

I Free translation from Ippocrate, Lettere sulla Follia di Democrito (1998, Liguori, Naples, ed. by Amneris Roselli, pp. 77, 79). 
embedded series of schemes involving pre-established knowledge about symptoms, illnesses, models of affliction and wider socio-moral notions of personhood and the Self. On the one hand, health care providers are confronted by such a sharp degree of cultural otherness that a real risk arises of inadequacy and even inability to apply routine processes of clinical intervention; at the very least, professional effectiveness is strongly reduced. On the other hand, in many cases immigrants lose their bearings when confronted with a biomedical "morality" - defining risk, disease, health and cure, and conditioning the perception and representation of body and emotions - that, for them, does not make sense. This paper - which is based upon two years of fieldwork in a Portuguese transcultural mental health service and the life history of Milocas, an African immigrant woman in Lisbon - proposes a reflection on the efficacy of these clinical settings.

The goal is to highlight how the frequent failure of therapeutic interventions in these settings could be interpreted as a consequence of the partial obfuscation or silencing of migrant voices as they speak about their afflictions, lived experiences and complaints, in a context where colonial power relations persist. Therapeutic systems influence the form that affliction takes in a society and may therefore exacerbate or alleviate existing inequalities.

Focusing on a specific clinical story, I will argue that psychobiological pathways involve complex biosocial dynamics the causation of which cannot be viewed in purely biological terms.

\section{MENTAL HEALTH SERVICES FOR MIGRANTS IN PORTUGAL}

This paper - drawing on a paradigmatic clinical history - invites reflection on the unknowing reproduction of colonial paradigms in psychiatric settings, with the effect of maintaining and re-enacting persisting structures of inequality. Based upon two years of fieldwork, this presentation underlines how the interpretation, diagnosis and treatment of "mental health" problems among immigrants can frequently be influenced by colonial legacies, also in "culturally sensitive" psychiatric programs.

Widespread immigration is a recent phenomenon in Portugal, only beginning to increase since the second half of the 1980s. Until the end of the 1990s migration to Portugal has been characterized by the consolidation of those coming from Portuguese-speaking African countries. Since 2000, despite the growth of Brazilian immigration, the most significant increase has been of Eastern Europeans. The largest number of immigrants is concentrated in the Metropolitan Area of Lisbon. With the increase in migration the face of the country has largely changed. Along with the more obvious economic and social changes, the reconfiguration of the therapeutic scenario is also of utmost importance. 
The state of health of immigrants has been a much debated topic over the past years. The issue has been fuelled by research reports on 1) cultural issues in the provision of services, 2) the discontent and dissatisfaction of migrants with the services, 3) the problems of the social management of medical pluralism and of creating multicultural mental health services. These studies have shown that health problems are exacerbated by poor integration into the general community, social and economic levels that are below the average of the country of residence, cultural and linguistic barriers, etc. Though these factors have long been acknowledged, and a number of campaigns took place to increase awareness of the risks of infectious diseases among immigrant populations, such topics have only recently become the matter for academic inquiry in medical anthropology and social sciences in general.

Up to the present, in Portugal, there has been little anthropological reflection on the encounter between different concepts of what constitutes mental health and appropriate treatment (Lechner 2005a, 2005b, 2009; Pussetti 2006). Such concepts are linked to specific historical and cultural contexts, and no thorough analysis of the opportunities and risks which stem from the encounter of nosological paradigms has been undertaken. The need for such a reflection is particularly urgent in the greater Lisbon area, where social and institutional geographies of healthcare are re-mapped; concepts of well-being and health are transformed; new interpretations and answers to suffering are created.

A recent report by the International Organization for Migration (IOM 2005) encourages the adoption in Europe of "culturally sensitive" health policies, in order to improve the quality of health services to a population that is becoming increasingly multicultural. An effort to create critical assessment in the area of transcultural mental health is being undertaken by several countries in Europe, among them Portugal. The health condition of immigrants and minority ethnic groups is considered, in Portugal as in the entire Europe, worse than that of the average European citizen. According to the Amsterdam Declaration Towards Migrant Friendly Hospitals in an Ethno-Culturally Diverse Europe, ${ }^{2}$ immigrants do not receive health care at the same level as the average population - in terms of diagnosis, treatment and preventive services - and health services are not sufficiently "culturally competent" and responsive to the needs of minorities. Health professionals' lack of awareness about cultural differences can make it difficult for both providers and patients to achieve the best, most appropriate care. This lack of cultural sensitivity, according to my data, is due to a combination of different factors, among which anthropological unpreparedness, resulting in an inability to recognize the differences, or leading to the attitude that our common humanity transcends differences. As a 
consequence, patient-provider relationship is affected and miscommunication and diffidence results.

Analyzing the interviews made with African immigrants hospitalized in a Portuguese mental hospital, it became apparent that these communities lack confidence in public mental health services and have a strongly negative and stigmatising image of mental hospitals. Often they reject the provider (and the entire system) even before any one-on-one interaction occurs because of distrust, fear or non-verbal cues that do not fit expectations. My Africans informants list stigma, shame and suspicion in mental health system as a reason for not seeking or delaying care. In most cases, they consider the psychiatric hospital as a detention centre for marginal or deviant people, comparing it to prison.

It is not my intention here to assume a highly critical or antipsychiatric position, affirming that practitioners are agents of social control whose primary role is to contain deviance. In the same way, I do not mean to consider actual professional medical behaviour and experiences as internally undifferentiated and homogeneous. My scope is rather to privilege the patients' perspective. The migrants' vision of the psychiatric institution recalls in many points the perspectives of Goffman and Foucault. The diffuse idea that psychiatric professionals are agents of force or that the institution is a space of control of societal problems is clearly reassumed in the paradigmatic idiom of the psychiatric hospital as space of confinement of the three Ps (pobres, pretos, putas, in Portuguese - poor people, blacks and whores).

For most immigrants, the mental hospital seems to work in a way similar to the police, the prison and other detention areas. Psychiatry, in this sense, militates against their interests and constitutes a value judgment, a form of confinement or social control, defending the privileges of the advantaged social classes and strengthening the stereotypes of the black urban migrant as the clandestine, the criminal, the alien, the contagious and the insane. My informants are generally extremely sceptical about psychiatric practices and treatments and scared by coercive psychiatric detention, by custodial and compulsory care, by the use of medications in order to control their bodies and minds and by interpretations of suffering which are often marked by misunderstandings, discrimination, violence and subjection. These concerns and fears are particularly meaningful if we consider that a psychiatric diagnosis is associated with stigmatization, isolation and social exclusion.

While generally Portuguese hospitals and health care centres have not developed specific practices for immigrants and there are no special facilities to which users can be referred, in recent years there has been an attempt to make mental health services for immigrants more culturally aware and sensitive. In one of the major Portuguese psychiatric hospitals, a courageous team has inaugurated a culturally sensitive mental health care centre for immigrants. In Portugal, providing better services for immigrants has never been a public 
health priority: it was therefore both an innovative and significant experiment. The nucleus was created by a psychiatrist, who, having developed a special interest in "transcultural psychiatry", put together a team of professionals and volunteers to provide a culturally sensitive service for migrants living in the area served by the hospital. Despite this commitment, the experience has in my opinion been quite negative.

The encounter with the cultural "other", who is used to different therapeutic theories and practices and holds alternative representations of the body and the emotions, has revealed in effect a legacy of colonial psychiatry. ${ }^{3}$ This legacy - incorporated, despite the best of intentions, as a constitutive element of diagnosis and treatment into the therapeutic practices of psychiatric counseling - pathologizes experiences and behaviours of marginalized people of non-Western origins, (re)producing discriminative attitudes.

It is not my intention here to explore the relationship between Portuguese psychiatry and politics, or - more generally - how medical technologies combine with social policies to enhance psychiatry's coercive power in the $20^{\text {th }}$ century. The historiography of colonial psychiatry (and unfortunately, the topic of Portuguese colonial psychiatry remains largely unheard of) has widely explored these connections and has thus opened up new approaches to the study of the history of psychiatry and medicine under colonialism. ${ }^{4}$ What interests us most here is how scientific knowledge and technological advances perpetuate the illusion of the superiority of Western psychiatry. The current pretension of Western psychiatry to identify, categorize, and dominate the irrational "other" is grounded on the same assumptions that upheld colonial psychiatry a century ago, and is at the root of the stereotypes that continue to mark contemporary therapeutic practice.

My fieldwork in psychiatric services for immigrants in Portugal has revealed how much this kind of prejudice and institutional racism ${ }^{5}$ still mark mental

3 I think it is important here to place my own theoretical stance within the specific tradition of the democratic psychiatry European movement. In particular, I am heavily indebted to the thought of the Italian psychiatrist Franco Basaglia, who came to understand madness as a human expression of undifferentiated human needs and as an oblique act of protest against a society that defines difference as deviance. His political and social agenda involved decriminalizing mental illness and unmasking psychiatric expertise as a justification for exclusion and confinement (Basaglia 1968, 1971, 1981, 1982).

4 See Bloch (1997); McCulloch (1995); Fassin (2000); Jackson (1999); Keller (2001); Littlewood and Bhugra (2001); Sadowsky (1999); Vaughan (1983); Shorter (1997); Porter (1988).

5 Institutional racism is a complex, multifaceted concept, wherein definitions often stress some aspects of the term and not others. Some definitions, for example, focus on the outcome of segregation and inequality, while others focus on the outcome of unearned privileges and advantages. Frequently, definitions stress that once racism takes hold and is embedded within institutions it does not require "intent". Rather, institutional racism can be perpetuated by seemingly benign policies, practices, behaviours, traditions, structures, etc., which is why it usually goes unchallenged. In other words, institutional racism is that which, covertly or overtly, resides in the policies, procedures, operations and culture of public or private institutions - reinforcing individual prejudices and being reinforced by them in turn. 
health workers' attitudes toward immigrants. Analyzing some emblematic cases - like the clinical history that I have chosen to present here -, we might find unexpected continuities between the viewpoints and diagnostic categories of colonial psychiatry and the current attitudes of health workers towards immigrant patients. Obviously, the medicalization or pathologization of immigrants' strange behaviour is not simply an act of individual discrimination or a consequence of ignorance. The problems lie much deeper than that, in the very definition of psychiatry as a scientific discipline, based on the assumption of the biopsychic unit of humankind, and therefore universally valid. Maybe it is not a problem of the practitioners - who are not racists and don't have colonial attitudes - but of the very functioning of the psychiatric system. The difficulty is that, because of its nature, because of its lack of objectivity, its dependence on "common sense" and the dubious validity of the criteria used for diagnosis, psychiatry is often open to political and social forces and effective in promoting the interests of dominant powers.

For this reason, I intend to question the validity and pertinence of the classification proposed by the Diagnostic and Statistical Manual of Mental Disorders (DSM-IV) that interprets experiences linked to different cultural horizons according to the rigid structure of biomedical nosology, pathologizing experiences and behaviours of marginalized people. All judgments of abnormal behaviour are rooted in conceptions of what an ideal life should be, along with judgments about proper and improper forms of behaviour. Moreover, decisions and judgments regarding the normality of various behaviours are made by medical and psychiatric professionals. In this sense, I consider medical designations of this nature as social judgments, and the adoption of a medical model of behaviour, a political decision. The imposition of a norm and the classification of other experiences according to the rigid grid of psychiatric nosology have in fact an evident political meaning: the overlapping of meanings is a mirror of the overlapping of powers.

In Arthur Kleinman's words,

One must ask, why should a discipline whose roots are so deeply planted in Western culture, whose major figures are almost entirely European and North American (and male), and whose data base is largely limited to the mainstream population in Western societies, why should so strongly Western-oriented a discipline regard cross-cultural research among the more than 80 percent of the world's people who inhabit non-Western societies as marginal? [...] Can psychiatry be a science if it is limited to middleclass whites in North America, the United Kingdom and Western Europe? (Kleinman 1988: xi-xii). 
As such, the DSM and the ICD (International Classification of Diseases) are seen by many authors as neo-colonialist endeavors: these two "bibles" of Western psychiatry, according to critics, declare certain behaviours as "deviant" using science and truth as an excuse, irrespective of historical and cultural variability. Labels become facts, while local meanings are lost in the translation to a foreign, academic language, and are stigmatized because of the distance from Western standards of normality, rationality, disease and illness. Despite recent efforts of some therapists to overcome these problems, power asymmetry, colonial legacies and misdiagnosis remain substantial barriers in the relationship with patients of culturally diverse backgrounds and worldviews.

\section{MILOCAS' CLINICAL HISTORY}

Everything is significant if you know how to read it... (Hall 1973: 98)

The case presented is only an example constructed from a wider set of cases upon which I worked in different mental health services for migrants, used to illustrate the possible misunderstandings in these complex encounters. Obviously, all the names and some details of the history have been changed to preserve the patients' privacy.

Milocas is a Guinean woman born in Bubaque, in the Bijagó Archipelago in Guinea-Bissau, in 1971. She is the second of three children. Her eldest brother was born after various miscarriages and died when he was three.

Her mother left her husband when Milocas was born, and moved to Bissau to improve her economic condition. Milocas' younger brother was born in Bissau the result of an occasional relationship of her mother, but died in his first year due to a congenital malformation. Milocas explains that he was a snake-child and that he had, therefore, to return to the sea. Milocas' mother dreamt of a future in Europe for her only daughter, a good job and a rich husband: trying to offer her a better life was her greatest worry. According to Milocas, it was with this purpose that her mother made a deal with a European woman, a trader working between Africa and Europe, and asked her to bring her daughter to Portugal, promising to pay for the service. As agreed, Milocas moved to Lisbon and quickly found a job and a partner, with whom she had a daughter.

Eight months ago, Milocas assaulted a European woman with long dark hair and eyes the colour of the sea - as Milocas described - because, according to her, the woman had been eyeballing her and wanted to kidnap Milocas' child. Milocas explained to the judge that she had attacked the woman to defend her daughter. Milocas complained that the voice of a European woman continuously asked her to pay off the debt that her mother had failed to make up for, paying with money or with her daughter's life. As a consequence of her 
behaviour and of her bizarre declarations to the judge, she was directly sent to psychiatric services.

Despite her internment in the facility, the voice never left her in peace and she has been deeply distraught as a result of the threats. She complains of continuous headaches and the unpleasant feeling of water entering her head through the fontanel, of insomnia, loss of strength, and swelling of the tongue and the throat, making it difficult for her to speak. She also talks about gynecological problems, like pains in her womb and amenorrhea. According to her interpretation, she can't have children anymore. She feels that she is under surveillance, and not truly free: everybody, she complains, asks her for things she cannot give, things she neither knows nor remembers. She always feels threatened by the police, by the doctors, and especially by that European business woman her mother made the deal with. She maintains that the origin of her problems has to be attributed to this woman to whom her mother owes money. She describes herself as a victim of this woman: "she is a witch", Milocas says. She also describes the business woman's perfect face, her fine and delicate features, her straight hair and her eyes blue like the sea. In these descriptions the business woman is clearly associated to the water element: her body is light, even transparent like water, bright like the sun reflected on the sea at sunset, she is in fact dazzling as light.

Months ago, before having being committed, she tried to solve her problem by consulting a curandeiro (healer) from Guinea-Bissau, who knew how to deal with this kind of situation given that the "white" doctors did not believe in these things. The curandeiro tried to cure her with purifying treatments (baths, emetics, laxatives, diuretics) and recommended that she make offerings and sacrifices to the sea. Milocas accomplished these prescriptions, but she was still scared, afraid and uneasy. "I don't believe in these things", she says, "I'm Christian and I never wanted to establish a relationship with this business woman." Nevertheless she carried on with this treatment for three months. She was fine: she stopped hearing the woman's voice as well as the water's noise in her head; her headache was gone, while her menstruation and energy had returned. As she felt better, she decided to stop the treatment that for her, at 30 Euros per week, was too expensive, in addition to the many offerings to the sea she was required to make including expensive items such as perfume or whiskey. Since deciding to stop, she has again felt worse.

To the doctors at the psychiatric hospital, she complains about muscular spasms, feeling short of breath and a loss of identity. She says that she continually hears the business woman's voice insisting that she has to pay off the debt. A few days before being committed in the hospital, Milocas had spent her entire month's salary going by taxi from her house to the beach, struggling against the fear of drowning or of being swallowed up by the sea. Talking to the doctors, Milocas continues to accuse her mother, obsessed by the desire of a 
luxurious life, of being the cause of her afflictions: she ignored the rules of society and separated from her husband, merely to satisfy her thirst for power and wealth. For these reasons, she is now alone, hated and envied by her compatriots, criticized and feared as a witch. It was because of other people's envy and because she had a lover that she should not have had, that her mother, according to Milocas, lost two children. When Milocas loses her sense of identity, conserving no memory of her actions, she accuses her mother of being a witch. Through Milocas' body, the angry voice of the business woman demands her mother to pay off the debt: "You once promised me your daughter, so you are the cause of her suffering." Interrogated about these affirmations, Milocas maintains that she doesn't remember anything.

When Milocas arrived at the psychiatric hospital, the doctors considered her behaviour typically psychotic and suspected schizophrenia. As a consequence of this diagnosis, and despite her resistance, Milocas was forced to take drugs. The therapy (a high dose cocktail of different neuroleptics, including Methotrimeprazine, Haloperidol, Olanzapine, Sulpiride, Loxapine) was meant to suppress her mental creations. To the great dismay of the physicians, however, the pharmacological therapy has not worked. After several months nothing has changed, except the fact that Milocas now looks like a zombie and expresses her uneasiness using the very discourse the physicians used to interpret her behaviour. "I am different from the others", she says, "now I know that I am sick, that I am crazy. The physicians have told me that I don't know what is real, because I'm crazy, I'm schizophrenic." A diagnostic category, in other words a label or a model, is now for Milocas a fact, destined to mark her life. She is now looked upon as crazy or sick, not only by the psychiatrists but by herself as well.

\title{
THE HOSPITALIZATION OF MILOCAS
}

\author{
In addition to the life-death cycle \\ Basic to nature, there is also \\ An unnatural living death: \\ Human life which is denied its fullness \\ (Paulo Freire 1970: 171)
}

Milocas' case provides an example of the complexities associated with culturally sensitive diagnosis. Her behaviour, bizarre for a Western observer, demands an explanation: it is strange, abnormal and irrational by our standards, and so insane. Psychiatric diagnosis has identified the views and attitudes of Milocas as different and unacceptable, and has declared her sick. The explanations that have been proposed have almost uniformly been psychiatric ones. Milocas' concern about others always observing her is considered as a symptom of a 
paranoid personality, without considering her illegal condition, the real experiences in her life related to discrimination, or the cases in which she was racially categorized because of her skin colour and appearance. Her references to the European business woman, interpreted as symptoms of her psychosis, clearly allude to the cult of the water spirit called Mamy Wata diffused all along the coast of West Africa. ${ }^{6}$ Mamy Wata is a powerful spirit living in the sea who frequently takes the form of a gorgeous European woman, usually naked, with blue eyes. She grants wealth, commodities and success in the "modern" world to her acolytes. But these favours, as everybody knows, are paid at a high price: a contract with Mamy Wata requires an important economic investment or promise of fulfilment of the debt. According to several interpretations, Mamy Wata (and the similar cults spread throughout the Guinea coast) expresses the paradigm of individual access to power (Jewsiewicki 2003: 11 l), her attributes combining on the one hand modernity and on the other "immorality" and corruption. Explicitly and clearly non-indigenous, linked to urban culture, she represents the fascination of material wealth and the seduction of modernity, or better, "the seducing dangers of materiality" (Gore 1997: 110), and is thus an expression of the contrasts and of the sudden social and economic changes of the colonial and postcolonial context.

In exchange for the wealth she provides, Mamy Wata demands sacrifices, such as the blood of animals and in some cases, it is alleged, even the blood of those closest to the beneficiary, such as family members, or better still the debtor's own newborn child. The fact that the creature is said to feed on the blood of such people suggests how material profit can come about at the cost of personal relationships. Here we perceive the inner connection between private wealth acquisition and loss of children and family. This idea is common in West Africa; rumours abound of wealthy people in conspiracy with spirits. It is the rich themselves who offer up the ones close to them in order to enjoy their seemingly good fortune to the full until, in many cases, they themselves also perish through their own deeds. Under the conditions of modern economic life in West Africa, where great differences in income prevail, suspicion of a contract with spirits as an explanation for the accumulation of individual wealth has grown in importance (Onwu 1985: 27; Gilliland 1986: 73).

The issue of a magical economy and of witchcraft emerged in recent African ethnographies as strictly linked to that of modernity, especially in relation to strategies for acquiring and controlling wealth (Argenti 2002). As Jean and John Comaroff underlined (1993), sorcery and witchcraft are not something relating to a "traditional village society", but rather ways in which the modern

6 See Szombati-Fabian and Fabian (1976); Salmons (1983); Drewal (1988); Bastian (1997); Gore and Nevadomsky (1997); Jell-Bahlsen (1997); Beneduce and Taliani (2001); Pussetti (2005: 107 -1 14). 
capitalist economy is experienced and conceptualized. It is the vocabulary of an occult economy (Comaroff and Comaroff 1999) that speaks of a manifest cash economy, generally describing dramatic shifts in power relations (see also Geschiere 1997). The widespread Mami Wata cult as well as the Bori cult of Niger for example - not to mention countless witchcraft associations such as the famla, the msa or the djambe of Cameroon (Argenti 2002; Warnier 1993; Geschiere 1997) - are typical in their reification of the powers of seduction and of the material trappings of Western wealth and modernity. Such cults seemingly make available to their devotees the fabulous riches that the majority of Africans can only dream of, and yet which are regularly paraded in front of them by the elites of their countries (Argenti 2002).

Regrettably, Milocas' assertions about witchcraft are only interpreted as symptoms of her paranoid personality based on typical African superstitions. Her bizarre behaviour and sensations are immediately considered as the outcome of inner disorders located within her brain.

The medical explanations I've collected identify Milocas' deviant behaviour with an organic pathology. Biomedical models seek the primary causes of Milocas' affliction in genetic and biochemical factors and so locate the pathological qualities of her psychological conditions in the physical properties of the brain, not in the symbolic systems of the mind. For this reason, from the point of view of the mental health practitioners I have interviewed, the techniques of psychiatry and psychology are regarded as legitimate ways to rectify these troubles.

Adopting the famous Gananath Obeyesekere's argument that in the psychiatric domain there are only illnesses and no diseases (1985: 136) - in the above discussion of Milocas' clinical case - I tried to refute the idea of mental disorder as a biological entity or, better, as a biological abnormality. Diagnoses, in my opinion, do not mirror distinct disease entities but rather have culturally determined explanations. In fact, the doctors agreed with me that there is no evidence that any of the common psychiatric disorders have a biological component. Mental disorders, they sustained, are classified on the basis of symptoms because there are as yet no biological markers or laboratory tests for them. Nevertheless, they supported the fact that if science, until now, has not individuated genetic causes, it does not mean that these do not exist. It is only a matter of time until all this is proven. This simple and commonly used response confirms that Milocas' condition is a medical problem probably biologic or genetic in origin; insofar, it can be treated with medication. "What a curious attitude scientists have - 'We still don't know that, but it is knowable and it is only a matter of time before we get to know it!' - as if that went without saying" (Wittgenstein 1980: 40).

In these confrontations, it was evident that psychiatrists and anthropologists were moving towards opposite philosophical poles, with the term 
"transcultural psychiatry" laden with different meanings for the two disciplines. Transcultural psychiatry to the psychiatrists emphasized the universal nature of disease entities. Transcultural psychiatry to the anthropologists emphasized the importance of understanding mental illness in the terms of the patient's cultural context and personal history, and examining, at the same time, the "culture" of psychiatry itself (Bains 2005). As a consequence of this confrontation, psychiatrists assumed more radically post-analytic and neoKraepelinian positions, and anthropologists became "too antipsychiatrists" (Estroff 1971).

Nevertheless - despite these continuous discussions and critical reflections, and ironically adopting the argument of medical authority or scientific truth Milocas' conduct was reduced to simple formulae, without any effort to embed it in wider semantic fields. The option of bargaining with the business woman, who has so much influence and so much power, paying this debt with an adequate ritual, has not even been contemplated: on the contrary, the final goal of treatment has been simply to silence her voice. Milocas' interpretation of her suffering has been silenced as an inappropriate way of interpreting human experience, in favour of the Western ideas of normality, deviance, health and illness, implicit within the biomedical model. Institutional racism occurs in many guises, but the imposition of a dominant culture's beliefs and values over those of people from minority groups constitutes one of its most powerful variants.

However, Milocas' bizarre behaviour challenges the psychiatric interpretative categories: her symptoms don't easily fit clinical categories and have resisted previous therapeutic treatments. The failure of these therapeutic interventions could be interpreted as a consequence of the partial silencing of her voices speaking about her very afflictions, about lived experiences and discontent, in a context of persisting colonial power relations. Milocas, like many other African immigrants I have met in psychiatric hospitals, expresses her suffering through interpretations that are different from those of biomedicine or of Western psychology. Her memory of the events preceding migration or of her daily problems and afflictions shifts continually from the register of possession to that of witchcraft and vice versa. As a matter of fact, social conflict, individualism, solitude and the search for well-being are the main sources of contemporary forms of witchcraft in Africa as well as the origin of cults like that of the water spirit Mamy Wata.

\section{CRITICISMS, DISCONTENTMENTS, CHALLENGES}

In order to understand Milocas's profile, the psychiatric categories have, in my opinion, little relevance. However, Milocas has been considered "ill" and diagnosed as afflicted by a serious psychotic disorder. And this label legitimizes 
medical intervention and medications. With a diagnosis of psychosis, Milocas' voice remains silent or unlistened to. Milocas is told that she is different, that she cannot be like this anymore. This diagnosis has participated in the construction of Milocas' social and personal identity as a sick and crazy person. It is not important if Milocas does not believe or perceive herself as crazy. The point is that she is treated as if she were and that she lives as if she were. The diagnosis invalidates everything she does or says - by labelling her as sick, "alien" to society, not to be trusted and not to be taken seriously.

What can psychiatry offer Milocas to replace her different identity and reality? Apparently, she has no alternatives: she is medicalized and committed at the hospital. Nobody has explored alternative explanations to provide an adequate answer to Milocas' suffering: in her case, for example, notions of causality as sorcery and spirit possession might have been more efficacious healing paradigms than biomedical ones, allowing her a different future. The goal of many traditional healing practices is in fact to redefine the place of the afflicted person in her or his social group. In this case, for example, notwithstanding her actual suffering, Milocas' affliction, if interpreted as a possession crisis of the Mamy Wata cult, might have found a happier conclusion, conferring a socially accepted status on her and acknowledging her outstanding attributes.

Unfortunately, adopting Susan Sontag's suggestion (1978) on the master diseases of our time - cancer, schizophrenia, AIDS -, biomedical metaphors and representation of Milocas' behaviour create a second illness in addition to the original affliction: the layers of stigma, rejection, fear and exclusion. Actually, it could have been far more useful considering her actual condition not as a fact but as a relationship, that is the product of a wider cultural scenario and of a classificatory process, based on social, political, ethical and aesthetical values.

Milocas' clinical history might be an unfortunate, isolated case, but it is nevertheless a paradigmatic example of the incomprehension and the presumption still marking mental health services for immigrants.

Many Portuguese doctors I interviewed affirm that psychotherapy with "African" patients is often doomed to failure, because of their incapacity to employ an abstract lexicon. This is due, they maintain, to their material and intellectual backwardness, and to their "inferior verbalization skills". The typical emotional verbalization of Western people, according to Julian Leff's theory of transcultural emotional differentiation (1981: 66), involves a greater capacity for introspection and better management of thoughts and sentiments. Moreover, my interviewees claimed that African immigrants are always potentially aggressive, that they often refuse to collaborate with therapists, arriving late, not taking drugs, not showing up at the sessions or shutting themselves off in a stubborn silence. When they decide to collaborate, they generally propose irrational interpretations of their suffering based on "beliefs" and 
superstitions. The term "beliefs", as opposed to "knowledge" (in Portuguese, crença and superstição in contrast to ciência and conhecimentos cientificos), is used very often by the medical staff during the interviews to stigmatize different interpretations and practices.

Paradoxically, despite the best of intentions, transcultural mental health practitioners even pathologize cultural beliefs, behaviours and practices, reading them as inappropriate interpretations of human experiences or even as symptoms of mental health problems. Possession cults or sorcery, in this sense, were considered incompatible with that "rational normality" psychiatrists were trying to restore, and were therefore targeted by therapy. Ironically, the goal of the self-styled transcultural staff was to "mainstream" the African patients into social and cultural "normality" as defined by the discourse of Western medicine and psychiatry. This attitude reproduces the existing hierarchy that privileges the rationality of medical science over that complex, elusive, and messy construct that is "culture" (Santiago-Irizarry 2001). Immigrants' culture, in this sense, is pathological in itself and an obstacle to the goal of assimilation. The medicalisation or the "psychiatricisation" (Knezevic and Jovancevic 2001) of immigrants' behaviours and experiences (interpreted as deviant and so as medical issues) is, in this perspective, a process destined to treat and drive their attitudes towards integration or assimilation into the host society. In this sense, I consider notions as integration or assimilation to be a political act destined to guide the "others" towards a direction (or toward a model of humanity) that we have chosen. Every form of rebellion, resistance or transgression is interpreted as the consequence of a social or psychological deviance or disturb. It is in the name of "assimilation" that the mental health professionals - behind the shield of science, rationality and universality - utilize the "treatment" to "teach" the right model or the correct way to the "others", with a paternalistic attitude.

My fieldwork in a psychiatric hospital has underlined how difficult it can be for Western mental health professionals to move beyond pathology-based thinking. The medical professionals I've interviewed were reticent to acknowledge the potential usefulness of alternative treatment systems: they were worried of being accused of pushing magical thinking, or of pretending to be traditional healers. They were afraid of losing credibility with the psychiatric hospital's board of directors.

While positions of open discrimination or intolerance are rare among health operators, my interviews revealed that these ethnocentric statements are not relics of the past, but are present in the projects and expectations of many of the health technicians that deal with immigrants. It is thus not surprising if, in a 2001 issue of the British Journal of Psychiatry, psychiatrist Andrew T. Cheng affirms that "there is no solid evidence for a real difference in the prevalence of common psychiatric disorders across cultures" and that "beyond culturally 
determined false belief, morbid suggestions and subjective complaints", there are objective problems and symptoms, real diseases and universal psychopathologies, that only Western psychiatrists succeeded in identifying. According to the author, it is evident that people of "less-developed societies", with personal vulnerability, low intelligence and limited knowledge of mental disorders, interpret illness as being physical in origin and complain therefore of somatic discomforts more often than Western patients. Here, as in the previous statements I have reported, we hear the distinct echo of colonial evolutionary ideology, according to which social and cultural phenomena were interpreted following Western paradigms while "traditional values" were regarded as evidence of backwardness.

I do not wish to say that recourse to mainstream psychiatry might not prove successful for immigrant patients. Many immigrants that I have interviewed have deliberately resorted to biomedicine in order to understand and find answers to their suffering. In these cases we can affirm, following Frankenberg (1988), that biomedicine is not hegemonic because it represents the dominant medical system, but because its domain is accepted and endorsed by people. We do not consult physicians because their social and medical views were forced upon us, but because we already share their views. In other words, those who turn to biomedicine do so not because they are passive victims of hegemony, but because the other possible explanations for their afflictions do not make sense to them.

In addition, it is not my intention to deny the usefulness and especially the charm and the performative and symbolic efficacy of medicines (Van der Geest and Whyte 1991). My interviewees often find Western drugs an attractive option: the pill is a concrete object endowed with special healing powers, a symbolically charged substance. Following Claude Lévi-Strauss' analysis of the efficacy of symbols, we can consider the drug both substance and symbol: for contemporary theorists of the symbolic efficacy of biomedicine, the same authority of scientific knowledge and of its objects produces its own healing effect.

The drug also objectifies the healing process and enhances the perception of suffering as something tangible. The purifying treatments that the Guinean curandeiro prescribed for Milocas share the same metaphorical logic, trying to remove the illness as an entity from her body. At the psychiatric hospital, in the same way, drugs can perform the same function. As Van der Geest and Whyte affirm:

[...] the metaphoric movements of medicines in relation to psychiatric conditions are particularly revealing, because such conditions are especially difficult to communicate. [Drugs] are 'facilitators' for establishing meaning and for communication. What Lévi-Strauss said about animals and plants 
in the essay on totemism applies to drugs in a psychiatric setting: they are 'easy to signify' [...] Thus, communication about medication becomes communication about problematic and ambiguous experiences (1991: 356).

Nevertheless, I think that Milocas' symptoms constitute a challenge as they seem to require a different explanation than that offered by biomedicine. There are issues that make sense within a specific discourse and that, when disconnected from this horizon of meaning, become senseless. Listening to how subjects interpret their affliction is an indispensable strategy for understanding the multiple symbolic dimensions of suffering and the different cultural forms that might integrate the healing process. Illness narratives are true and genuine devices for the symbolic organization of the healing experience and of the therapeutic process, playing a fundamental role in the creation of meanings through which the subjects try to objectify and make sense of their experiences.

Considering the Milocas' illness narrative, in my opinion, Western diagnostic categories violate the meaning of her experience, and thus the knowledge on which it is based. Furthermore, because Milocas' behaviour and spiritual experiences are not plausible realities for mainstream psychiatric assessors, psychopathology remains the only possible explanatory model. The "new transcultural psychiatry" acknowledges the importance of spirituality in patients' lives in order to offset the tendency of mental health professionals to ignore or pathologize unfamiliar experiences. However, in daily clinical practice, psychiatrists continue to employ their narrow conceptions of reality, normality, rationality and health, pathologizing unfamiliar perceptual sets and world-views.

In this paper, I have tried to question the adequacy of Western diagnostic systems and to advocate a flexible therapeutic space that allows the interplay of many different interpretations and coping strategies to deal with the crisis. Instead of relegating cultural aspects to the rank of incidental curiosities, it would have been necessary in the case described to take into account the way in which Milocas and her reference group define and make sense of the situation she was living. Recognizing Milocas as a person, as a political and moral subject, without forcing her to be what we suppose she must become - a body domesticated by our socio-sanitary practices - is to admit that this woman has something to say about her own suffering and about the practices destined to treat it.

Milocas' case shows how the rigid structure of biomedical nosology can pathologize the experiences and behaviours of others (those regarded as alien), reproducing the already existing structures of social inequality. 


\section{REFERENCES}

ARGENTI, N., 2002, "Youth in Africa: a major resource for change", in de Alex Waal and Nicolas Argenti (eds.), Young Africa: Realising the Rights of Children and Youth. Trenton and Asmara, Africa World Press, 123-153.

BAINS, J. 2005, "Race, culture and psychiatry: a history of transcultural psychiatry", History of Psychiatry, 16 (2): 139-154.

BASAGLIA, F., 1968, L'Istituzione Negata. Torino, Einaudi.

—, 1971 , La Maggioranza Deviante. Torino, Einaudi.

__, 1981, Scritti I, 1953-1968: Dalla Psichiatria Fenomenologica all'Esperienza di Gorizia. Torino, Einaudi.

—_, 1982, Scritti II, 1968-1980: Dall'Apertura del Manicomio alla Nuova Legge sull'Assistenza Psichiatrica. Torino, Einaudi.

BASTIAN, M.L., 1997, "Married in the water: spirit kin and other afflictions of modernity in Southeastern Nigeria, Journal of Religion in Africa, 22 (2): 116-134.

BENEDUCE, R., and S. TALIANI, 2001, "Un paradosso ordinato: possessione, corpi, migrazioni”, Antropologia, 1 (1): 15-42.

BLOCH, M., 1997, "La psychanalyse au secours du colonialisme”, Terrain, 28: 103$-118$.

CHENG, A.T.A., 2001, “Case definition and culture: are people all the same?", British Journal of Psychiatry, 179: 1-3.

COMAROFF, J., and J. COMAROFF, 1993, "Introduction", in John Comaroff and Jean Comaroff (eds.), Modernity and its Malcontents: Ritual and Power in Postcolonial Africa. Chicago and London, University of Chicago Press, xi-xxxvii.

— 1999, "Occult economies and the violence of abstraction: Notes from the South African postcolony”. American Ethnologist. 26 (3): 279-301.

DREWAL, H.J., 1988, "Performing the other: Mammi Watta worship in West Africa", The Drama Review, 32 (2): 160-185.

ESTROFF, S.E., 1971, “The anthropology-psychiatry fantasy: can we make it a reality?”, Transcultural Psychiatric Research Review, 15, 209-213.

FASSIN, D., 2000, "Les politiques de l'ethnopsychiatrie: la psyché africaine, des colonies britanniques aux banlieus parisiennes”, L’Homme, 153: 231-250.

FRANKENBERG, R., 1988, "Gramsci, culture, and medical anthropology: Kundry and Parsifal? Or rat's tail to sea serpent?”, Medical Anthropology Quarterly, n. s., 2 (4), Gramsci, Marxism and Phenomenology: Essays for the Development of Critical Medical Anthropology: 324$-337$.

FREIRE, P., 1970, Pedagogy of the Oppressed. New York, Seabury Press.

GESCHIERE, P., 1997, The Modernity of Witchcraft: Politics and the Occult in Postcolonial Africa. Charlottesville and London, University of Virginia Press.

GILliLAND, D., 1986, African Religion Meets Islam: Religious Change in Northern Nigeria. New York, University Press of America.

GORE, C., 1997, "Mami Wata: West Africa", in J. Middleton (ed.), Encyclopedia of Africa South of the Sahara, vol. 3, 108-1 10.

GORE, C., and J. NEVADOMSKY, 1997, "Practice and agency in Mammy Wata worship in Southern Nigeria", African Arts, 30 (2): 60-69.

HALL, E., 1973, The Silent Language. New York, Anchor/Doubleday. 
IOM, 2005, World Migration Report 2005: Costs and Benefits of International Migration. Geneva, International Organization for Migration. Available at <http://publications.iom.int/ ServletSearchPublication? event $=$ detail\&id $=4171>($ accessed 20/09/05).

JACKSON, L., 1999, “The place of psychiatry in colonial and early postcolonial Zimbabwe, International Journal of Mental Health, 28 (2): 38-71.

JELL-BAHLSEN, S., 1997, "Eze Mmiri Di Egwu, The Water Monarch is Awesome: Reconsidering the Mammy Water myths", in F.E.S. Kaplan (ed.), Queens, Queen Mothers, Priestesses, and Power: Case Studies in African Gender. New York, The New York Academy of Sciences, 103-134.

JEWSIEWICKI, B., 2003, Mami Wata: La peinture urbaine au Congo. Paris, Gallimard.

KELLER, R., 2001, "Madness and colonization: psychiatry in the British and French empires: 1800-1962", Journal of Social History, 35: 295-326.

KLEINMAN, A., 1988, Rethinking Psychiatry: From Cultural Category to Personal Experience, New York, Free Press.

KNEZEVIC, M., and M. JOVANCEVIC, 2001, "Model of providing psycho-social aid to refugees and displaced persons: records of the Croatian Psychiatric Association", European Journal of Psychiatry, 15: 33-47.

LECHNER, E., 2005a, «O sofrimento dos migrantes e o encontro de ordens simbólicas», Revista de Psiquiatria do Hospital Amadora-Sintra.

— , 2005b, «Uma aproximação à diferença: imigração e cuidados de saúde», Revista Transcultural, APPPT, Lisbon.

—-, (ed.), 2009, Migração, Saúde e Diversidade Cultural. Lisbon, ICS.

LEFF, J., 1981, Psychiatry around the Globe: A Transcultural View. New York, Marcel Dekker.

LITTlewood, R., and D. BHUGRA, 2001, Colonial Psychiatry. New Delhi, Oxford University Press.

McCulloCH, J., 1995, Colonial Psychiatry and the African Mind. Cambridge, Cambridge University Press.

OBEYESEKERE, G., 1985, "Depression, Buddhism, and the work of culture in Sri Lanka", in A. Kleinman and B. Good (eds.), Culture and Depression. Berkeley, University of California Press, 134-152.

ONWU, N., 1985, "Igbo religion: its present situation", Africana Marbugensia, 18 (2): 15-92.

PORTER, R., 1988, A Social History of Madness: The World Through the Eyes of the Insane. New York, Weidenfeld and Nicolson.

PUSsetTI, C., 2005, Poetica delle Emozioni: I Bijagó di Bubaque (Guinea-Bissau). Rome and Bari, Edizioni Laterza.

— , 2006, "A patologização da diversidade: uma reflexão antropológica sobre a noção de culture-bound syndrome", Etnográfica, X (1): 5-40.

SADOWSKY, J., 1999, Imperial Bedlam: Institutions of Madness in Colonial Southwest Nigeria. Berkeley, University of California Press.

SALMONS, J., 1983, "Mammy Wata”, African Arts, 10 (3): 8-15.

SANTIAGO-IRIZARRY, V., 2001, Medicalizing Ethnicity: The Construction of Latino Identity in a Psychiatric Setting. Ithaca, NY, Cornell University Press.

SHORTER, E., 1997, A History of Psychiatry: From the Era of the Asylum to the Age of Prozac. New York, John Wiley and Sons.

SONTAG, S., 1978, Illness as Metaphor. New York, Farrar, Straus and Giroux. 
SZOMBATI-FABIAN, I., and J. FABIAN, 1976, "Art, history and society: popular painting in Shaba, Zaire", Studies in the Anthropology of Visual Communication, 3: 1-21.

VAN DER GEEST, S., and S.R. WHYTE, 1991, "The charm of medicines: metaphors and metonyms", Medical Anthropology Quarterly, 5: 345.

VAUGHAN, M., 1983, "Idioms of madness: Zomba lunatic asylum, Nyasaland, in the colonial period”, Journal of Southern African Studies, 9: 218-238.

WARNIER, J., 1993, L'esprit d'entreprise au Cameroun. Paris, Karthala.

WitTGEnStein, L., 1980, Culture and Value. Oxford, Blackwell, ed. G.H. von Wright, trans. P. Winch.

Etnografias de novos encontros clínicos: as batalhas emocionais do imigrante e a psiquiatria transcultural em Portugal - Chiara Pussetti - CRIA, Portugal - chiara_pussetti@hotmail.it

Fundamentando-se em dois anos de trabalho de campo num serviço de saúde mental para imigrantes em Lisboa, o artigo sublinha como a interpretação psiquiátrica da experiência emocional do desenraizamento, da carência de casa e da (não) pertença por parte dos migrantes pode ser influenciada por legados coloniais. Esses legados - incorporados, apesar da melhor das intenções, como elementos constitutivos do diagnóstico e tratamento nas práticas terapêuticas do acompanhamento psiquiátrico - fazem com que as experiências e comportamentos de pessoas marginalizadas vindas do mundo não ocidental sejam tratados como patologias, reproduzindo atitudes discriminatórias e racismo institucional.

PALAVRAS-CHAVE: antropologia das emoções, antropologia médica crítica, etnopsiquiatria, legados coloniais, diáspora africana. 